\title{
Importance of boron in fruit nutrition
}

\author{
Nagy, P. T. ${ }^{1}$, Kincses, I. ${ }^{2}$, Nyéki, J., ${ }^{3}$ Soltész, M. ${ }^{4} \&$ Szabó, Z. ${ }^{3}$ \\ IInstitute of Environmental Sciences, Faculty of Natural Resources Management and Rural Development, \\ Károly Róbert College, Mátrai str. 36. Gyöngyös, H-3200, Hungary nagypt@ karolyrobert.hu \\ ${ }^{2}$ Department of Agricultural Chemistry and Soil Science, University of Debrecen, Centre of Agricultural and \\ Applied Economic Sciences, Faculty of Agricultural and Food Sciences and Environmental Management, Hungary \\ ${ }^{3}$ University of Debrecen Centre for Agricultural and Applied Economic Sciences, \\ H-4032 Debrecen, Böszörményi út 138., Hungary \\ ${ }^{4}$ Collage of Kecskemét, Faculty of Horticulture, H-6000 Kecskemét, Erdei Ferenc tér 1-3.
}

\begin{abstract}
Summary: Boron (B) is an essential micronutrient in plants especially in fruits. Despite of this fact there are very few information about its application, uptake and symptoms in Hungarian fruit growing sector. Nowadays we should consider the effects of weather conditions on soil B availability increasingly according to the climatic anomalies. Identifying of internal and external symptoms of plant parts (leaf, fruit) is help for growers to recognize the deficiency and excess symptoms in time. Methods and application rates of boron fertilization provide further information for growers to achieve qualify-oriented fruit growing among Hungarian conditions. The aim of this minireview is to focus on the importance of boron in fruit nutrition.
\end{abstract}

Keywords: fruit, sympton, soil, application

\section{Introduction}

Boron (B) is an essential micronutrient in plants and has a great role in blossom and yield. The major role of B in fruit trees involves fruit set (Faust, 1989). Apple, pear and cherry flowers are very high in B. The B needed in the flower is transported mainly from the reserves in the adjacent branches and not from the roots during the development flower. It is essential for reproduction, aids in the formation of pollen germination and pollen tube growth. Boron aids in the metabolism of hormones and in the translocation of calcium, sugars and growth regulators, required for protein synthesis. In addition $B$ is important for early growth, flowering and fruit set (Kamali and Childers, 1970), maintains balance between sugar and starch, aids in auxin regulation and of course it is necessary for cell division and differentiation, and root tip development.

Despite of these facts, boron deficiency was the most widespread of all the micronutrient deficiencies in many crop regions from tropical to temperate zones (Shorrocks, 1997) in the last decades. It follows from the lack of boron application in nutrient management and from the occurrence of weather extremes, because the climatic anomalies have huge role in the development of boron deficiency, mostly in fruit plantations. To solve it, the boron maintenance has become as a part of the orchard solid-foliar fertilizer program all over the world.

\section{Soil B availability}

All soils contain some boron but the amount varies greatly depending largely on boron content of the parent material and the weathering action (Boynton, 1966; Wann, 1966).

Boron is required only in very small amounts by fruits, but when it is deficient disorders can occur. Boron occurs in the soil primarily as boric acid or borate. This may be present in the soil solution or adsorbed on soil particles (Mengel and Kirkby, 1979).

The nature of borate adsorption in soils is still not well understood. As the soil $\mathrm{pH}$ is lowered, borate adsorption decreases.

Nowadays, the hot water-soluble B is regarded as plant available soil B. Wojcik (2003) proposed that the critical value for hot water-soluble B concentration in the soil is 0.45 $\mathrm{mg} / \mathrm{kg}$, for the most fruit crops grown under temperate climate. Under this value, symptoms of B deficiency may be occurred.

The reasons of boron deficiency are various. On the one hand, it follows from the unavailability of soil boron. Therefore the fact that boron deficiency symptoms of fruits may be induced by heavily liming of some acid soils has been well established. Boron deficiency of fruits often occurred on soils with high carbonate of lime content and alkaline reaction. 
$\mathrm{Ca}$ and $\mathrm{Mg}$ borates are very insoluble and this may play some parting the lime effect. Granite soils are generally more likely to be boron deficient than other soils. High clay soil contents also impair B availability, probably due to borate adsorption (Mengel and Kirkby, 1979). Beside this, it seems likely that other factors are involved as well.

Boron availability is also related to seasonal behaviour because weather conditions affected it strongly.

\section{Effects of weather conditions on soil B availability}

Waterlogged and very dry soils can lead to boron deficiency, as roots are unable to take up nutrients. Deficiency appears to be more prevalent in a dry summer following a wet winter or spring (Mengel and Kirkby, 1979).

In soils of low boron availability, dry weather may bring on boron deficiency symptoms of fruit trees under some conditions; in fact this association caused "drought spot" to be used as a descriptive name of one symptom.

There is a close relationship between summer rainfall and the occurrence of the internal cork symptom of boron deficiency.

In those years, when the summer rainfall is deficient internal cork occurred, and the symptom was more widespread when the deficiency occurred in May as well.

It seems that any weather conditions causing moisture stress in the trees during a dry growing season increases the occurrence of symptoms.

Internal cork is common when sunshine and temperature are above average.

Since moisture deficiency is a predisposing factor conditions favouring moisture conservation, and irrigation should to some extent decrease the severity of damage from boron deficiency in years when it occurs.

Not only is shortage of available water a factor favouring appearance of boron deficiency symptoms, but also is excess of soil moisture.

Effects of moisture deficiency and excess are probably indirect ones, and are simply expressions of inefficient absorption by the root system under those conditions. Following these facts it seems that there is rather limited ability of fruit trees to store mobile boron that can be used in growing regions during temporary shortages.

\section{Symptoms of boron deficiency}

A minimum boron threshold value of $35-40 \mathrm{mg} / \mathrm{kg}$ in late summer mid-shoot leaves has been established for most deciduous fruit tree species (Jones et al., 1991). If the boron concentration is under these values boron deficiency has occurred. Symptoms of B are developed on fruits, vegetative parts (twigs and leaves) and blossom as well. Symptoms are often noticed in the fruit before symptoms become visible in the shoots.

\section{Fruit symptoms}

The most common symptoms of boron deficiency in the apple are found in the fruit. Boron deficiency can appear as either internal or external cork. Fruit affected by internal cork often show no external symptoms. The disorder is seen when fruit are cut open.

Internal cork is the more common form of deficiency from USA to China.

Internal cork may appear any time from shortly after bloom until harvest. It is thought to occur when deficiency occurs later than eight weeks after petal fall. Dry climatic conditions are usually the trigger of these processes all over the world (Dart, 2004).

Small, round water-soaked spots appear throughout the flesh (Photo 1). The spots dry out and turn very dark from the centre outwards, finally forming brown spongy lesions, often with a greenish halo. The dead cell masses become dry, hard and corky before harvest. Lesions in the core region sometimes run together, dry out and form cavities. The brown tissue normally occurs closer to the core than the skin. As the corky tissue dies fruit becomes misshapen. Moreover, many of affected fruits drop in early summer and some of those that mature may be small.

The surface contours of severely affected fruit may be rough and irregular. Late season internal cork has larger lesions with less sharply defined margins. The texture of the lesions is soft and spongy but they may occupy a large proportion of the flesh.

External cork is more likely to occur if deficiency occurs early in the growing season. It usually develops before the fruit is half grown and may develop soon after bloom. It causes irregular depressions to appear as fruit matures. Dark brown to greenish-black lesions with a green border occur on or just beneath the skin, mostly in the depressions. Affected areas are apt to be irregular in shape (Photo 2). They may occur in any position on the fruit but are most common at the calyx end. These may later become dry and corky. When fruit is cut open, corky lesions are scattered throughout the flesh.

Raised brown or reddish spots may occur on the surface also. These, later crack and the skin dries up and scales off, leaving a rough corky layer.

The incidence of internal or external cork or both on apples seems to depend on variety and the date at which symptoms first develop. The late season internal cork symptom is the most common one and it often occurs in marginal deficiency situations in favourable years for it without any other symptom (Dart, 2004).

Abnormally dark red colour of apples also shows the deficiency of boron. The first recognition of boron deficiency is often follows abnormally heavy preharvest drop.

Generally problem of growers that the fruit symptoms of boron deficiency can often be confused with calcium deficiency, especially where cracking has not developed. However, the two disorders can be distinguished by the features in the table 1 . 


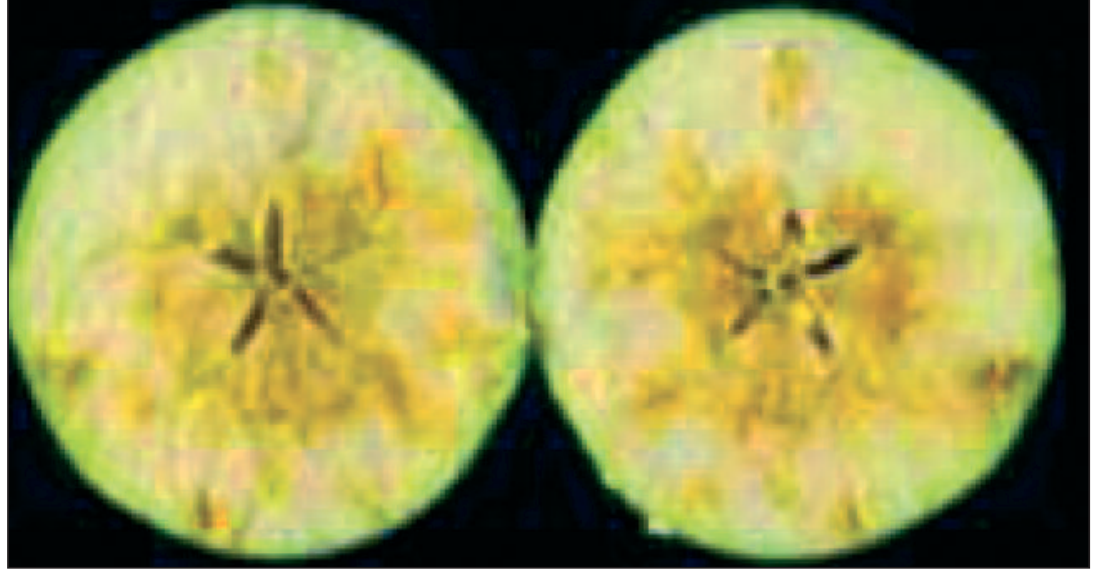

Photo 1: Internal cork symptoms in Granny Smith apple (brown tissues around cores)

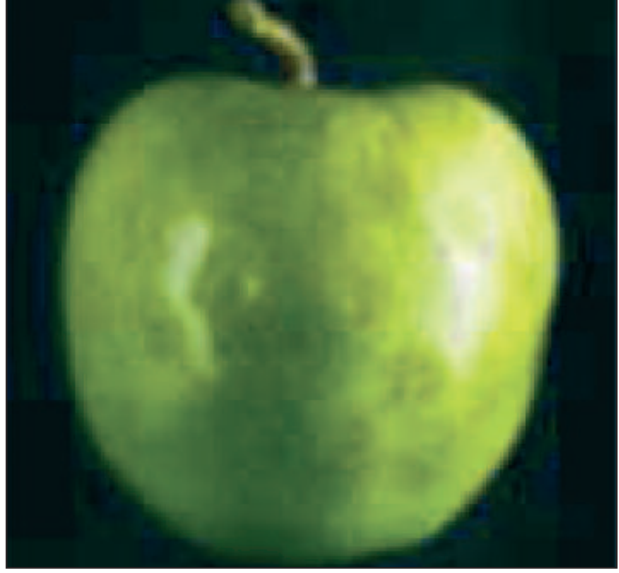

Photo 2: External cork symptoms in Granny Smith apple (bumpy spots and irregular shape)
Table 1: Comparing fruit symptoms of Boron and Calcium deficiency

\begin{tabular}{|l|l|}
\hline \multicolumn{1}{|c|}{ Boron deficiency - "cork" } & \multicolumn{1}{|c|}{ Calcium deficiency - "bitter pit" } \\
\hline $\begin{array}{l}\text { Brown tissue occurs near the core } \\
\text { and on the surface }\end{array}$ & $\begin{array}{l}\text { Brown tissue appears closer to the } \\
\text { skin }\end{array}$ \\
\hline Cracks may develop in fruit & No cracking occurs storage \\
\hline Symptoms do not worsen in storage & $\begin{array}{l}\text { Symptoms often appear worse, or } \\
\text { develop after }\end{array}$ \\
\hline
\end{tabular}

Source: Adapted and modified from Dart (2004)

\section{Twig and foliage symptoms}

Besides the fruit symptoms of boron deficiency there are some important symptoms in vegetative organs. These are far less common than the fruit symptoms and the association between leaf analysis and deficiency symptoms is not as good as in the case of fruits.

Foliage symptoms are more sporadic in their appearance and seem to occur mainly under conditions of very severe deficiency.

The earliest symptom seen was a failure of both leaf and flower buds to "break" normally when spring growth started. These buds remained alive until full bloom when a majority of them turned brown and died.

If deficiency occurs mid-season, the dieback of shoots can occur in late summer. The first evidence is a yellowing and red veination of the terminal shoot leaves which may later show marginal and tip necrosis. Small brown necrotic areas develop at the leaf tips and margins. The twigs may die from the tips. Death of small areas of bark near the shoot tip is followed by progressive death of most of the inner bark and cambium from the tip backward. If the boron deficiency is not alleviated promptly the terminal may die back into wood several years old. Directly behind the point of death, lateral dormant buds push into growth and these growths may die back causing a dense bushy "witches broom". This abnormal growth is very subject to winter injury. So the symptoms of boron deficiency were similar to winter injury and as such were difficult to differentiate. The outstanding difference was that with winter injury there was death of tissue taking place shortly after exposure to extreme cold. With boron deficiency however there was no evidence of death of tissue until after growth started in the spring.

Shoot abnormalities, and shoots with shortened internodes and bearing dwarfed strap-shaped leaves are also part of this symptom complex. These shoots are sometimes referred to as "rosettes". Rosette may develop at any time during the season and often followed by dieback.

Dieback can also be a symptom of problems other than boron deficiency. Copper deficiency is also results the symptom of dieback. Moreover, boron deficiency can also lead to rosette symptoms in leaves. Leaves become dwarfed, thickened and brittle and are found on very shortened twigs. Note that zinc deficiency can also cause leaf rosettes, but the presence of corky lesions in fruit will distinguish between the two.

In sum the most frequented and characterized boron deficiency symptoms of different organs were showed in Table 2.

Table 2. Common fruit and vegetative boron deficiency symptoms

\begin{tabular}{|l|l|}
\hline \multicolumn{1}{|c|}{ Fruit symptoms } & \multicolumn{1}{c|}{ Vegetative symptoms } \\
\hline Small, flatten or misshapen fruit & Internal bark necrosis (bark measles) \\
\hline Drought spot & $\begin{array}{l}\text { Dead terminal shoots and dieback., } \\
\text { sometimes one may see a witch's- } \\
\text { broom effect }\end{array}$ \\
\hline Internal cork & $\begin{array}{l}\text { Yellowing and red veins on the } \\
\text { terminal shoots }\end{array}$ \\
\hline Cracking and russet & Shorten internodes \\
\hline Premature ripening & $\begin{array}{l}\text { Smaller, stiff, thick, brittle leaves } \\
\text { with smooth margins }\end{array}$ \\
\hline Increased fruit drop & $\begin{array}{l}\text { Death of small areas of the bark the } \\
\text { tip of the shoots followed by } \\
\text { progressive death of the inner bark } \\
\text { and cambium }\end{array}$ \\
\hline Seed count may be low & Blossom blast \\
\hline
\end{tabular}


The main blossom symptom is the blossom blast, when the flowers wither but remain on the tree. Moreover, in boron deficient trees the leaves are chlorotic between the veins and the serrations along the margins are resinous and necrotic (Wann, 1966).

\section{Boron toxicity}

Excess of boron also may have important effects on the fruit. These take several forms but all seem to be related to earlier maturation and shortened storage life of the fruit. Earlier harvest and serious breakdown of late stored fruit are common symptoms of excess boron. Preharvest dropping and change from green to yellow ground colour are hastened on trees heavily fertilized with boron.

Boron toxicity cause leaf injuries, defoliation and shoot abnormalities also. One of most distinctive visible symptom is a loss of green colour and yellowing of the leaf along the midrib and larger lateral veins.

The occurrence of B toxicity symptoms in leaf margins of old leaves has long been interpreted as an indication of the immobility of B in plants (Oertli, 1993).

Differently from this, Eaton et al., (1941) suggest that some plant species did not express this symptom of $\mathrm{B}$ toxicity. Eaton observed that in stone fruit trees such as prune (Prunus domestica) and apricot, the typical symptoms of B toxicity are absent.

Instead of the marginal leaf burn so typical of B toxicity, some species (pear, apple, plum and hybrid species (almond $\mathrm{x}$ peach) exhibit $\mathrm{B}$ toxicity as tip die back in young shoots, profuse gumming in the leaf axil and the appearance of brown corky lesions along stems and petioles. In apple, apricot and pear, bud abscission and death is also observed (Crandall et al., 1981; Dye et al., 1983; Hansen, 1974). Other researchers also reported similar findings and have shown that B does not accumulate in leaves of these species to any significant extent even when trees are grown at excessive levels of B (El-Motaium et al., 1994; Hansen, 1955; Woodbridge, 1955).

Boron toxicity symptoms usually appear in the summer following an excessive boron application. In severe cases the tips of current season's branches withered and die back, cankers developed along the stem and gumming is appeared mostly at the end of leaves.

Table 3: The most common boron toxicity symptoms

\begin{tabular}{|l|l|}
\hline Fruit symptoms & Vegetation symptoms \\
\hline Reduced or no yield & Dead terminal; buds and dieback \\
\hline $\begin{array}{l}\text { Increased internal breakdown after } \\
\text { harvest }\end{array}$ & Marginal leaf chlorosis and necrosis \\
\hline $\begin{array}{l}\text { Increased watercore development } \\
\text { after harvest }\end{array}$ & Brown spots on twigs and bark \\
\hline Premature ripening & Defoliation \\
\hline
\end{tabular}

If the injury is mild, small necrotic areas developed in the leaves along the midrib. Later the necrotic areas dropped leaving perforations along the midrib. Beside necrotic spots, small cankers developed on the underside of the midrib and in the petiole.

Stone fruits from trees showing boron toxicity symptoms were malformed and kernel development was poor.

Boron toxicity is not commonly present in orchards. Its main visual symptoms are represented in Table 3.

\section{Method of B application}

Nowadays two main approaches to control of boron deficiency have been used: ground application and foliar spraying. Earlier, injection technique was successfully applied to control at boron deficiency but it has some disadvantages like laborious procedure and it causes some injuries at the point of injection even under the best conditions due to the local enrichment of boron.

The preferred time to apply B to the soil is about silver tip to green tip stage. Boron is absorbed from the soil solution by roots, mainly as undissociated boric acid, and behaves as a mobile nutrient in the soil. Therefore, small soil applications easily provide adequate B to trees. However, commercial broadcast guidelines for soil B application must deal with the difficulty of equally distributing small amounts of fertilizer (Sánchez and Righetti, 2005).

Wojcik (2006) pointed out that high yield of tart cherry can be obtained on soils with water-soluble B concentrations as low as $0.32 \mathrm{mg} \mathrm{kg}^{-1}$. Moreover, Wojcik supposed that on sandy and sandy loam soils effect of foliar B sprays on plant nutrition is not only related to $\mathrm{B}$ absorption rate by leaves but also to uptake rate of this nutrient by roots (Wojcik et al., 2008).

Although the soil application is the most spread and accepted in boron maintenance, some authors pointed out that soil-applied B remained mostly in the roots while very little was translocated to the above-ground portions of the tree at full bloom (Sánchez and Righetti 2005;Wojcik et al., 2008).

At present, most growers apply foliar B spraying. For some authors, the preferred application time is early fall after harvest to promote boron reutilization before defoliation.

The application of B in autumn results in enhanced B concentrations in buds and flowers in the subsequent spring. In plum, Hanson and Breen (1985) determined that dormant buds contain about $18 \%$ of the B present in senescent leaves, the remainder of this B is supplied from bark and wood of nearby branches. Boron applied to leaves of these trees in autumn apparently increases pools of B in these subtending tissues and plays a critical role in supplying the $\mathrm{B}$ requirements of flowers in the spring.

Moreover, autumn B application (October) increases leaf B concentrations $400 \%$ within 24 h of B application; over the subsequent 30 days this $\mathrm{B}$ concentration decreases dramatically, such that at leaf senescence (November) both 
treated and untreated leaves have similar B concentrations. During this period, and continuing through to early bud swell (February), buds on branches that received autumn foliar B have significantly higher $\mathrm{B}$ concentrations than control branches. As buds swelled during early spring, and up until flowering (April), this difference in bud B concentrations increases such that at flowering, flowers on treated branches have B concentrations $200 \%$ higher than control flowers (Brown and Shelp, 1997).

Sprays also can be applied in the early spring at the prepink-to-pink blossom stage (Peryea, 1994)., because transitory low B status may limit fruit set, the goal of foliar B programs is to increase B in flower buds to help fruit setting.

For some authors, the preferred foliar application time is early fall after harvest, but sprays also can be applied in the early spring prebloom to bloom at petal fall $\left(1^{\text {st }}\right.$ or $3^{\text {rd }}$ cover sprays) (Peryea, 1994; Peryea et al., 2003; Wojcik et al., 1999)).

Foliar fertilization of boron is generally successful because deliverable amounts are enough to meet most tree requirements.

In a study conducted in Poland (Wojcik et al., 1999) four B applications were compared: (1) Soil application ( $2 \mathrm{~g} /$ tree); (2) Spray application $3 \times$ before bloom ( $0.67 \mathrm{~g}$ per tree); (3) Spray application after bloom $3 \times(0.67 \mathrm{~g}$ per tree $)$; and (4) No B, the results indicated that all treatments except for control that had no B added increased in B concentration in apple fruit. Highest concentration was found in fruits sprayed after bloom and soil applications. In later publications, Wojcik stated that the efficiency of foliar B sprays was higher than soil B application (Wojcik, 2006; Wojcik et al., 2008).

Their results showed that soil B fertilization improved root development and tree vigor. Leaves of trees supplied with B to the soil had higher B concentration and chlorophyll, net photosynthetic rate, stomatal conductance, and activity of catalase and glutathione reductase than those of the control plants. Boron fertilization, regardless of application mode, increased fruit yield (Wojcik et al., 2008).

They also found that apple fruits of trees fertilized with B to the soil were bigger, more coloured, richer in B, and had higher soluble solids concentration, and titratable acidity compared to those of the control trees (Wojcik et al., 2008).

Contrary to this, in an earlier experiment Wojcik could not find relationship between $B$ treatments and mean fruit weight and titratable acidity of fruit (Wojcik, 2006).

Correspondingly, Peryea (2002) found that fruit quality was not affected by the B spray treatments in any year. Flower cluster and leaf B concentrations returned to near or at control levels in the season following the last spray application, suggesting limited accumulation and/or remobilization of intra-tree $\mathrm{B}$ reserves. This last observation validates the recommendation for annual B fertilizer applications to maintain adequate tree B status (Peryea, 2002).
However, yield may increase following foliar B application even for trees that exhibit leaf B concentrations within the desirable range (Chaplin et al., 1977). This observation indicates that standard leaf analysis may not be suitable for diagnosing transient B deficiency early in the growing season (Brown, 2001).

The influence of late-season B application on the bud B concentration and fruit set was studied in sweet cherry (Prunus avium L.) by Usenik and Štampar (2007).

They also pointed out that B application results in increased B concentration in flower buds and the fruit set was influenced with cultivar, boron application and micro location also.

\section{Application rates}

Nowadays the rates of application differ for different regions all over the world.

Application rates should be based on both foliar and leaf analysis (Table 4). General recommendations where $\mathrm{B}$ is deficient are to apply 0.4 to $0.8 \mathrm{~kg}$ per acre of actual B in two-four separate sprays, from prebloom to bloom at petal fall. Sometimes, further post-harvest foliar spraying is advised approx. $0.8 \mathrm{~kg}$ per acre actual B.

Ground application should be adjusted to the condition of orchard (age, density, rootstock, soil parameters). Accepted dose of application is 2-3 gr of actual B per tree when $\mathrm{B}$ deficiency symptoms can be visible.

Table 4: Range of Boron in soil and leaf tissues ( $\mathrm{mg} / \mathrm{kg}$ )

\begin{tabular}{|c|c|c|c|}
\hline & Deficiency & Sufficiency & Toxicity \\
\hline Soil & $<0.5$ & $0.5-1.0$ & $>1.0$ \\
\hline Foliar & $<20$ & $20-60$ & $>80$ \\
\hline
\end{tabular}

Source: Jones et al., 1991

Boron is absorbed from the soil solution by roots, mainly as undissociated boric acid, and behaves as a mobile nutrient in the soil. Therefore, small soil applications easily provide adequate $B$ to trees. However, commercial broadcast guidelines for soil B application must deal with the difficulty of equally distributing small amounts of fertilizer. Recently, the increasing popularity of mechanical irrigation systems, especially drip irrigation, make fertigation a useful technique for delivering precise amounts of nutrient to individual trees. Routine additions of $\mathrm{B}$ in fertigation systems are likely to become increasingly common.

\section{Aknowledgement}

Research was sponsored by NFÜ TECH_08-A3/2-20080373 grant. 


\section{Literature cited}

Boynton, D. (1966): Apple nutrition. 1-50. In: Childers N. F. (ed.): Fruit nutrition. Horticultural Publications, Rutgers University in New Brunswick, N.J . ( $2^{\text {nd }}$ ed.)

Brown, P. H. \& Shelp, B. J. (1997): Boron mobility in plants. Plant and Soil, 193: 85-101.

Brown, P. H. (2001): Transient nutrient deficiencies and their impact on yield - A rationale for foliar fertilizers? Acta Hort., 564: 217-223.

Chaplin, M. H., Stebbins, R. L. \& Westwood, M. N. (1977): Effect of fall-applied boron sprays on fruit set and yield of 'Italian' prune. HortScience, 12: 500-501.

Crandall, P. C., Chamberlain, J. D. \& Garth, J. K. L. (1981): Toxicity symptoms and tissue levels associated with excess boron in pear. Comm. Soil Sci. Plant Anal., 12: 1047-1057.

Dart, J. (2004): Boron deficiency (cork) in pome fruits. Agfact H4.AC.2, second eds. www.agric.snw.gov.au

Dye, M. H., Buchanan, L., Dorofaeff, F. D. \& Beecroft, F. G. (1983): Dieback of apricot trees following soil application of boron. New Zealand J. Exp. Agric., 11: 331-342.

Eaton, F. M., McCallum, R. D. \& Mayhugh, M. S. (1941): Quality of irrigation waters of the Hollister area of California. US Dept. Agr. Tech. Bull., 746.

El-Motaium, R., Hu, H. \& Brown, P. H. (1994): The relative tolerance of six Prunus rootstocks to boron and salinity. J. Amer. Soc. Hort. Sci., 119: 1169-1175.

Faust, M. (1989): Physiology of temperate zone fruit trees. Wiley, New York

Hansen, C. J. (1955): Influence of rootstock on injury from excess boron in Nonpareil almond and Elberta peach. Proc. Amer. Soc. Hort. Sci., 65: 128-132.

Hansen, P. (1974): The effect of boron upon leaf development and growth of the apple cultivar 'Cox's Orange Pippin'. J. Hort. Sci., 49: 211-216.

Hanson, E. J. \& Breen, P. J. (1985): Effects of fall boron sprays and environmental factors on fruit set and boron accumulation in 'Italian' prune flowers. J. Amer. Soc. Hort. Sci., 110: 389-392.

Hanson, E. J. 1991. Movement of boron out of fruit leaves. HortScience, 26 (3): 271-273.

Jones, J.B., Wolf, B. \& Mills, H.A. (1991): Plant Analysis Handbook. Micro-Macro Publishing, Inc. Athens, Georgia, USA
Kamali, A.R. \& Childers, N.F. (1970): Growth and fruiting of peach in sand culture as affected by boron and fritted form of trace elements. J. Amer. Soc. Hort. Sci., 95: 652-656.

Mengel, K. \& Kirkby, E. A. (1979): Principles of plant nutrition. ( $2^{\text {nd }}$ ed.) Int. Potash Inst. Berne, Switzerland

Oertli, J. J. (1993): The mobility of boron in plants. Plant and Soil, 155/156: 301-304.

Sánchez, E.E. \& Righetti, T.L. (2005): Effect of postharvest soil and foliar application of boron fertilizer on the partitioning of boron in apple trees. Hortscience, 40: 2115.

Shorrocks, VM. (1997): The occurrence and correction of boron deficiency. Plant and Soil, 193: 121-148.

Peryea, F.J. (1994): Boron nutrition in deciduous tree fruit, p. 95-99. In: A.B. Peterson and R.G. Stevens (eds.) Tree fruit nutrition. Good Fruit Grower, Yakima, Wash.

Perya, F.J. (2002): Properties and performance of boron spray products for apple. Acta Hort., 594: 211-215.

Peryea, F.J., Nielsen, D. \& Neilsen, G. (2003): Boron maintenance sprays for apple: Early-season applications and tank-mixing with calcium chloride. HortScience, 38: 542-546.

Usenik, V. \& Štampar, F. (2007): Effect of late season boron spray on boron accumulation and fruit set of 'Summit' and 'Hedelfinger' sweet cherry (Prunus avium L.). Acta agriculturae Slovenica, 89: $51-58$.

Wann, F. B. (1966): Cherry nutrition. In: Childers N. F. (ed.): Fruit nutrition. Horticultural Publications, Rutgers University in New Brunswick, N.J. (2 $2^{\text {nd }}$ ed.)

Wojcik, P., G. Cieslinski \& A. Mika (1999): Apple yield and fruit quality as influenced by boron applications. J. Plant Nutrition, 22 (9): 1365-1377.

Wojcik, P. \& Wojcik, M. (2003): Effect of boron fertilization on 'Conference' pear tree vigor, nutrition, and fruit yield and storability. Plant and Soil, 256: 413.

Wojcik, P. 2006. 'Schattenmorelle' tart cherry response to boron fertilization. J. Plant Nutrition, 29 (9): 1709-1718.

Wojcik, P., Wojcik, M. \& Klamkowski, K. (2008): Response of apple trees to boron fertilization under conditions of low soil boron availability. Scientia Horticulturae, 116: 58-64.

Woodbridge, C. G. (1955): The boron requirements of stone fruit trees. Can. J. Agric. Sci., 35: 282-286. 